\title{
CORRIGENDUM
}

Genes \& Development 32: 297-308 (2018)

\section{Corrigendum: Transcription elongation rate affects nascent histone pre-mRNA folding and $3^{\prime}$ end processing}

Tassa Saldi, Nova Fong, and David L. Bentley

In the above-mentioned article, the affiliation originally provided was incomplete. The complete affiliation is as follows: Department of Biochemistry and Molecular Genetics, RNA Bioscience Initiative, University of Colorado School of Medicine, Aurora, Colorado 80045, USA. This has been corrected online.

doi: $10.1101 / \operatorname{gad} .314948 .118$ 


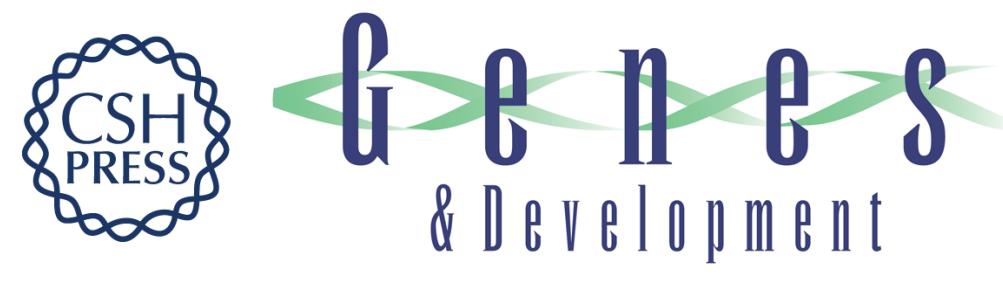

\section{Corrigendum: Transcription elongation rate affects nascent histone pre-mRNA folding and 3 ' end processing}

Tassa Saldi, Nova Fong and David L. Bentley

Genes Dev. 2018, 32:

Access the most recent version at doi:10.1101/gad.314948.118
Related Content Transcription elongation rate affects nascent histone pre-mRNA folding and 32 end processing
Tassa Saldi, Nova Fong and David L. Bentley
Genes Dev. February, 2018 32: 297-308

\section{License}

Email Alerting Receive free email alerts when new articles cite this article - sign up in the box at the top Service right corner of the article or click here.

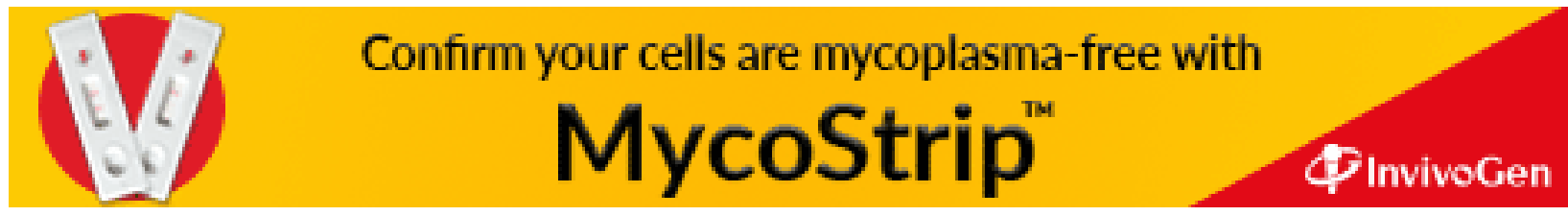

